Urbanizing the Iranian Public: Text, Tehran and 1922

Elling, Rasmus Christian

Published in:

Middle Eastern Studies

DOI:

10.1080/00263206.2018.1540414

Publication date:

2019

Document version

Early version, also known as pre-print

Citation for published version (APA):

Elling, R. C. (2019). Urbanizing the Iranian Public: Text, Tehran and 1922. Middle Eastern Studies, 55(3), 301318. https://doi.org/10.1080/00263206.2018.1540414 
NOTE: Author's pre-print version. Reference should be made to the published version, which will be available in Middle Eastern Studies in 2019.

\title{
Urbanizing the Iranian Public: Text, Tehran and 1922
}

\begin{abstract}
.
By using the heuristic device of transpatialization and the methodology of urban cultural studies, this article argues that the 1922 serialized novel Tehrān-e Makhuf (Dreadful Tehran) by Seyyed Mortaza Moshfeq-e Kazemi (1902-1978), with its distinctly urban modes of imagination and production, at once reflected and propelled a process that can be termed the urbanization of the Iranian public. The article analyses the literary techniques with which Moshfeq contributed to this process; the circumstances and context in which the novel was produced; and the ideological change reflected in the author and his work. The article thus sheds light on a crucial stage in modern Iranian history by unravelling some of the socio-spatial intertwinements that made that history.
\end{abstract}

Written in the years leading up to Reza Shah's ascendance to the throne of Iran, the 1922 novel Tehrān-e Makhuf (Dreadful Tehran) ${ }^{1}$ by Seyyed Mortaza Moshfeq-e Kazemi (1902-1978, henceforth Moshfeq) has been widely recognized as Iran's 'first social novel' or 'the first social realistic novel' in Persian. ${ }^{2}$ In this article, ${ }^{3}$ I will substantialize that recognition by arguing that the novel at once reflected and propelled 
a crucial shift in cultural frames and forms, which can be called the urbanization of the Iranian public.

Three aspirations underpin this argument. Firstly, in his recent work, Cyrus Schayegh offers an interpretation of the "[i]ntertwinements of socio-spatial fields" ${ }^{4}$ that created the modern Middle East. He does so with the aid of transpatialization: a 'heuristic umbrella' with which historians can understand 'exemplary instances of the fast-rhythmed reciprocal transformation of cities, regions, states, and global networks'. While the scope of the present article is much narrower than that of Schayegh's magisterial work, I will argue that Tehrān-e Makhuf, its circumstances and its production do indeed constitute an exemplary instance: the intertwinement, in an urbanizing public, of social and spatial processes.

Thus, while scholars have already produced literary analyses of Tehrān-e Makhuf, ${ }^{6}$ and others have touched upon its sociological aspects, ${ }^{7}$ I am concerned here with its role vis-à-vis a public. ${ }^{8}$ I will argue that with distinctly urban modes of production and imagination, Moshfeq did more than simply present the city as a setting or backdrop: through representations of the city, his work channelled larger questions about modernization, national identity, state-building and social change. In bringing urban life and space to view in ways hitherto unseen, it summoned its readers to understand themselves as individuals, community and nation in a different light. Moshfeq thus at once captured and helped create an urban moment in Iranian history with significant consequences.

Secondly, as the socio-spatial intertwinement I am interested in relates to literature, I employ the methodology of urban cultural studies, defined by Benjamin Fraser" as 'a dialogue between art and society - between textual / representational 
(humanities) understandings of culture and anthropological, geographical, sociological (social science) approaches'. ${ }^{10}$ With an attention to the dialectical relationship between material conditions and cultural imaginaries, ${ }^{11}$ such an approach enables me to analyse Tehrān-e Makhuf as an urban product rather than 'just' a piece of literature. ${ }^{12}$

Accordingly, the analysis is not limited to content: The novel is understood within an assemblage of concrete places and processes in the city, of more abstract notions and paradigms (such as 'Iranian-ness', 'modernity') and of personal, intellectual, cultural, social and political contexts. To borrow an expression from Amy Wigelsworth, I am interested in the 'overlapping of text and context' - because in Tehrān-e Makhuf, just as in the object of Wigelsworth's study, the city is both subject matter and contextual frame of reference, 'defining the terms for the text's production and reception'. ${ }^{13}$

This leads to the final aspiration, which is to shed light on an important but less studied period in Iranian history. ${ }^{14}$ I will argue that an analysis of Tehrān-e Makhuf and its circumstances can help us towards a stronger understanding of the shift in a crucial segment of the Iranian intelligentsia from the ideals of the Constitutional Revolution towards authoritarian modernisation. This shift, Stephanie Cronin has argued, ${ }^{15}$ should be seen as a process rather than as a sudden rupture. I hope to show that cultural products such as Tehrān-e Makhuf acted as propellants in this process, in a sense preparing society for, and pushing it in the direction of the significant alterations that Iran would witness under Reza Shah's reign from 1925 onwards.

I will begin by briefly introducing the author, the plot of the novel and Tehran at the time. Then I will examine key themes in the work as they relate to the urbanization of the Iranian public. Thirdly, I will discuss, in turn, Moshfeq's experience with Tehran 
at the time of writing, his sources of inspiration and his politics. Finally, I will draw together my findings about the socio-spatial intertwinement of text, time and city.

\section{Moshfeq and Tehran}

Moshfeq was the son of Mirza Reza of Tafresh, an official in the Ministries of Interior and Finances who was away on duty across Iran for much of Moshfeq's childhood. ${ }^{16}$ In his autobiography, Moshfeq describes his family as a'yān ('nobility') and hence upper or upper middle class. However, he also mentions that his grandfather lost much of his wealth and status in the turmoil following the 1905-11 Constitutional Revolution.

Enrolled in the prestigious Servat High School and then in Iran's first Westernstyle polytechnic institution, the Dār-ol-Fonun, Moshfeq was taught by Europeantrained teachers in a progressive environment. In 1922, he continued his studies in political science in Germany followed by economics in France. Returning to Iran in 1926, he worked in the Ministry of Public Services, from 1927 in the Supreme Court and from 1934 in the Ministry of Foreign Affairs, where he served as head of various offices and finally as Vice Minister. Moshfeq also served as Iran's Resident Minister in Syria and as Ambassador to India and various European countries. He died in a car crash in Paris in 1978.

In 1922, when he was just 20 years old, Moshfeq published Tehrān-e Makhuf as a serialized novel in the newspaper Setāre-ye Iran. In 1923, it was published as a book after which Moshfeq followed up with the sequel Yādegār-e yek shab, 'Reminiscence of One Night'. Later, the two appeared as a single book, which was then translated into a number of languages in the region. Moshfeq also wrote essays, articles and translations as well as a couple of less successful novels and finally a two-volume memoir. ${ }^{17} \mathrm{He}$ had 
a lifelong interest in theatre and was part of an intellectual circle that advocated rapid modernization of Iranian society and culture. While in Berlin, he was the managing editor of Nāme-ye farangestān, a 'modernist Germanophile journal with unabashed admiration for Western civilization, ${ }^{18}$ and later, he contributed to the magazine Irān-e Javān ('Young Iran'), which advocated secular nationalism.

Tehrān-e Makhuf stands out as Moshfeq's single most important work. It was written in a simple language, at times resembling a detailed journalistic report, at other times digressive, circular or even rambling; but throughout, the novel follows a straightforward plot. Although it was a trailblazer, 'different from all other novels of the period, ${ }^{19}$ and while it paved the way for generations of socially engaged fiction writing in Iran, Tehrān-e Makhuf was not a gem in terms of literary quality. The author himself has excused this with his young age and inexperience. ${ }^{20}$ What nonetheless makes the work stand out was its ability to deliver a devastating, mostly realistic depiction of Tehrani society wrapped inside a somewhat mediocre love story.

Tehrān-e Makhuf is set in a period roughly spanning 1917 to 1921, i.e. under the rule of Ahmad Shah Qajar. The protagonist is Farrokh, whose father was a Qajar courtier that - not unlike the author's own family - had lost his wealth and position during the Constitutional Revolution. Farrokh falls in love with Mahin, daughter of his aunt and her greedy, corrupt nouveau riche husband F.-os-Saltaneh ${ }^{21}-$ one of the story's key antagonists. F.-os-Saltaneh has plotted to give away Mahin to the scoundrel Siyavash Mirza, son of Prince K. Mirza. In return, F.-os-Saltaneh expects to be promoted in K. Mirza's ministry and/or groomed for a seat in parliament. Dead set on his plan, F.-os-Saltaneh refuses to accept Mahin and Farrokh's love, causing them great distress and despair. Despite numerous initiatives - including abducting Mahin en route 
to Qom and hiding her in a village north of Tehran, as well as petitioning both Siyavash Mirza and the authorities - Farrokh ultimately fails to marry Mahin. The novel ends tragically with Farrokh imprisoned far from Tehran.

In the sequel, Yādegār-e yek shab, Farrokh escapes from custody in the mountains of North Iran, travelling on through Tsarist Central Asia during the Russian Civil War. After a detour with rebels in North Iran, Farrokh fortuitously enrols in the Cossack Brigade and rides into Tehran with the victorious Reza Khan during the February 1921 coup. Back home, Farrokh takes revenge over his adversaries and marries 'Effat, a woman of noble heritage whose malevolent first husband had caused her fall into prostitution until Farrokh saved her from a brothel (in Tehrān-e Makhuf). Finally, Farrokh turns to a quiet life at home with his son. Save for one aspect from the sequel, this article will deal only with the first volume, which is more rewarding in terms of urban analysis.

Tehrān-e Makhuf was written and plays out on the backdrop of several overlapping issues: the impact of the Constitutional Revolution of 1905-11, which brought about demands for broad social change as well as illiberal reaction, instability and elite reconfigurations; the weakness of the state apparatus during regional unrest and repeated interventions by foreign powers; the decline of the Qajar dynasty (17961925) that culminated with the establishment of the Pahlavi dynasty (1925-1979); women's rights and the plight of prostitutes; and, more generally, social restrictions and inequality.

The novel was also written at a time when Tehran underwent major changes. In the 1910 s and early 20 s, nearly $80 \%$ of Iranians lived outside of cities, including a large nomadic population, which often had little interaction with the somewhat ineffectual 
state apparatus. Under Naser-od-Din Shah (1848-'95), Tehran underwent significant growth and change, budding industrialization and attempts at urban planning. Reforms and new techniques of governance facilitated the growing commodification of urban land, which in turn impacted on class politics. ${ }^{22}$ Tehran was the centre for Europeaneducated modernizers and the object of schemes such as improved sanitation and public hygiene, higher education and modern policing. However, these initiatives often fell short of needs and demands, and Tehran largely remained underdeveloped when Moshfeq wrote Tehrān-e Makhuf.

We will now look at how Moshfeq's Tehrān-e Makhuf interacted with an urbanizing Iranian public. A public, to paraphrase Michael Warner, is an autotelic, circular, self-created relation between strangers; it is a social space that exists by virtue of participation in its discourse and poetic world-making. ${ }^{23}$ Moshfeq, to be precise, was not the 'producer' of the urbanization of the Iranian public any more than he was a product of it. He did, however, employ certain techniques in his storytelling that enabled him to address issues of the day through representations of urban space and society.

I will now present three of these techniques.

\section{Navigating class with a new compass}

Tehrān-e Makhuf used representations of urban life to introduce the reader to Iranian class relations in a novel way. From the first page and throughout, Moshfeq applies a numbered categorization of social classes directly onto Tehran's geography: the 'first' or upper classes living in the spacious, green, peaceful surroundings of peaceful periurban North and West Tehran, the 'second' or middle classes in the centre and the 
'third' or lower classes in the densely crowded, noisy, insalubrious quarters of the south and east. Rather than merely insinuating class difference through personal names, titles and professional labels, clothing, and so on, Tehrān-e Makhuf expressed it in spatial and temporal terms.

Sleep, for example, is presented as a privilege: the 'third class', Moshfeq explains, are forced to get up every day in the early morning and struggle to secure a little money - 'rarely more than a qerān' - selling groceries or dairy products. The 'second class', including state employees, entrepreneurs, scholars, journalists, clergymen and would-be politicians, can sleep a little longer. But even though this class sees itself as 'guides' and 'leaders' of society, it too is unprotected from those in actual power. $^{24}$

Indeed, when the second class gets up in the morning, the 'first class' is still asleep, comfortably surrounded by 'parks and property and jewels and money'25 in the wealthy outskirts of Tehran. These are the ashräfiyān (noblemen) and Qajar princes (shāhzādegān), born into wealth and luxury and enjoying an urban life with fresh air, amble living space and a privileged mode of transport, the doroshkeh (horse and buggy). While the middle classes could take the văgon (horse-driven wagons), all others were forced to walk long distances by foot - even when the city was engulfed by a dust storm, which is the case in the opening lines of the novel.

The lowest class dwells in neighbourhoods such as Chaleh Meydan in southern Tehran. This area, which used to be a landfill, is described as the quintessential slum with 'cramped', 'twisting and turning' and 'sunken' alleyways. Its inhabitants are the poor, downtrodden masses as well as outlaws who will brawl over minor monetary disagreements or even kill each other over the territorial transgressions of one dasteh 
(ritual procession group) into the quarter (mahalleh) of another dasteh during the holy month of Moharram. ${ }^{26}$

Behind small, dirty windows, thieves and fugitives throng together in hangouts (pātoq), and 'the lowest classes from within each profession [senf] ${ }^{27}$ congregate in lurid coffeehouses (qahveh-khāneh). There are dens so dirty and full of smoke from samovars, hookahs and opium pipes that only addicts can frequent their gloomy spaces without nauseating. ${ }^{28}$ Chaleh Meydan is an unenlightened microcosm, its denizens oblivious of not only the world but even of what goes on in Tehran - including changes to the government of Iran. In the scalar politics of knowledge, south Tehran (pāyinshahr, literally 'below-city'), is a downward-looking pit of ignorance beneath a pinnacle of power in the north of the city (bālā-shahr, 'upper-city'), which opens up and looks out to the world.

Yet, not everyone was born into misery, let alone deserves it. In one of Chaleh Meydan's coffeehouses we find Javad, who will become our protagonist's assistant. Javad's tumbling decline through Tehran's social layers begins in a relatively large household of shoemakers in midtown, middle-class Sangalaj until one day typhus strikes, forcing surviving family members to move from a khāneh-ye melki (real estate house) to an otāq-e kerāyeh (rented room) in Chaleh Meydan. The fall down the economic ladder is thus reflected in geographical displacement, the reduction in living space and in change in legal status of dwelling.

Indeed, in those precarious days, downward social mobility can even cause those in 'the first class' to fall into the second - the protagonist, Farrokh, being the prime example. Farrokh's family, presented throughout as 'genuine aristocracy ${ }^{29}$, have seen their standing and privileges usurped by the ruthlessly competitive and morally 
unrestrained nouveaux riches. We see how the scoundrel F.-os-Saltaneh, who has built his own wealth on opportunism and crime, dares to describe Farrokh as lät-o-lut, 'pauper' or 'riff-raff' ${ }^{30}$ Farrokh's restiveness and rebelliousness feeds on his feeling of injustice as much as on his broken heart.

But while Farrokh is self-identified with the educated elite and pronouncedly bourgeoisie in values, the destabilization of social ranks and ensuing disillusion also bestows him with a mobility to traverse class geography as a sort of privileged peripatetic. His sincere and unprejudiced personality affords him friendships in all strata so he can explore areas otherwise considered dangerous and off-limits to someone of his standing.

When Farrokh goes to Chaleh Meydan to hire Javad, he changes from farangi$m a$ ' $\bar{a} b$ or 'European-style' clothes into those of a poor person in order to avoid suspicion. While his 'slim, white hands' ${ }^{31}$ give him away, his respectful attitude still makes him appear trustworthy to Javad and other working-class characters. Having experienced his own social déroute, Farrokh can supposedly relate to the pains of the toiling classes. It is also among them that he discovers the authenticity and sincerity that has allegedly faded in the upper classes:

Farrokh had great faith in the simple-hearted people who lived in the south of the city ... and he knew that if one behaved in a courtly and respectful manner with them, they would be ready to perform any kind of selfsacrifice... Farrokh was certain that the city's southern inhabitants were incapable of being duplicitous and deceptive; indeed, these gentlemen [javānmardān] were not like certain others of their fellow townsfolk [hamshahri] who would only perform a task if it could result in money or 
material benefits ... He knew that this [lower] class of society refrains from lying and because their sustenance and subsistence depends on the strength of their own shoulders, they are not like certain loafers and leeches in society who spend all of their time on toadying and sponging off other people's tables. ${ }^{32}$

Here we see how social geography becomes a moral compass for a public of hamshahri (fellow townsfolk) as southerners are ascribed a range of qualities to contrast the moral bankruptcy of northerners. However, in confirming the moral superiority of the lower classes, the author does not relinquish his protagonist's privilege: he reassures his readers that the working class is still willing and able to self-sacrifice when presented with a just cause by the elite. And that is exactly what Javad, the protagonist's 'friend' from Chaleh Meydan ends up doing when he goes to jail for Farrokh's actions.

Through Farrokh, Moshfeq laid the city and its inequalities bare. By teasing out the spatial and temporal dimensions of class difference, by mapping this difference onto Tehran's geography and by presenting the city as a divided, differentiated space, he raised broader questions of social relations, urban culture and elite composition for the novel's urbanizing public.

\section{Addressing injustice in a city of fear}

Tehrān-e Makhuf is often translated as Appalling or Horrible Tehran, but I will argue that Dreadful or Frightening is more apt. The Tehran we witness is full of khowf, terror and fear, and Moshfeq took his public to the roots of this fear.

A key technique was thus to address social ills by giving them an address: in other words, to single out and then zoom in on particular, named nodal points in the city 
- actually existing places, neighbourhoods, streets, squares and buildings - where a particular problem was concentrated or exemplified. In the following, I will examine some of these nodal points and the problems of power abuse, vice and gendered oppression they represent. I will also explore some addresses of respite from fear.

The recurrent theme of corruption is introduced through the presence and movements of the antagonist Siyavash Mirza, who is presented throughout as one of the farzandān-e lus-e ashrāf, 'spoiled children of the aristocracy'. ${ }^{33}$ We first meet Siyavash at his father's home: an 'emārat, a large building or villa set in a garden full of flowers in the affluent southwest. Here, we find him lounged in a leather armchair in front on his sycophantic servant, surrounded by expensive carpets, decoration and furniture. ${ }^{34}$ The classy setting is contrasted with Siyavash's vulgarity: he is drinking 'araq, smoking cigarettes and talking about prostitutes - indeed, he is so uncouth that he does not even know how to sit properly on a chair.

The talk of one particular prostitute gets Siyavash excited and with his servant, they embark on a night-time journey towards a brothel in the northeast of Tehran. On this crosstown trip, Farrokh meets his rival for the first time. Siyavash intercepts Farrokh on Naderi Street in the city centre, grabs him by the collar and demands to know if he too is heading for a brothel. The situation nearly escalates but the antagonist proceeds, drunk and lustful, to harass a woman on the street. The incident is a clear case of aristocratic power abuse right in the heart of the city - and it is also here that the gendered dimension of power abuse first comes to view.

As the story progresses, it is evident that street harassment is in fact one of Siyavash and his peers' favourite diversions. In one scene, Siyavash explains that he has pre-fabricated letters of invitation to be handed out to random women in Lalehzar 
Street, Tehran's centre of entertainment, asking the ladies to join him at home to 'drink a glass of sherbet and smoke a cigarette'. ${ }^{35}$ In another scene, Siyavash is boasting about women in each corner of the city, explaining that "with my wealth and youth, I should have all women in this city...,36

In other words, Moshfeq shows that harassment and deceit in public space are some of the ways in which Siyavash and his peers use the city and its hapless inhabitants to satisfy their desires. We are shown - on actual, named streets - how the decadent members of the elite treat the city as their personal playground.

Siyavash also bring us to an address at Kont Junction ${ }^{37}$ in North Tehran: the kolub-e shāhanshāhi or Royal Club. With its affluent and influential clientele, this elite space turns out just as decadent as the brothels and coffeehouses. In the Royal Club, we find the antagonists and their peers playing baccarat while revealing their obsession with jens-e latif ('the weaker sex') and flirting with the wives of foreign diplomats. ${ }^{38}$ We hear them boasting about wealth and blabbering about world politics and we see them as fundamentally ignorant and self-obsessed. As such, Moshfeq is able to expose this majestic and supposedly progressive, modern space as a centre of moral corruption.

Indeed, we find the country's notables in compromising situations across the city: a state official in an opium den and a prince in a brothel; a clergyman taking a bribe and a dignitary beating up a homeless man. We are privy to the elites conversing about contracting sexually transmitted diseases from prostitutes - it even seems Siyavash has set up a chemistry lab for post-coital self-cleansing. ${ }^{39}$ State institutions are described as at best inefficient; the police station is 'a centre of corruption and injustice'. ${ }^{40}$ Indeed, we witness structural injustice across the institutional landscape: in the 'adliyeh or court, in the nazmiyeh or police station and in the habs or prison; it is 
laid brutally bare as a public spectacle ( $m a$ 'reke) when Javad, Farrokh's poor helper, is flogged on a city square.

The first chapter to introduce the recurrent theme of prostitution is simply headlined 'The Sick Quarter'. In Ateshkadeh Street in the northeast, we find miserable women who have ended up in a brothel (ruspi-khāneh), many against their own will. It emerges, of course, that this part of the city is not 'sick' because of the prostitutes but rather because of the men whose actions have forced them there. Again, by naming the street on which the brothel is found, Moshfeq wanted to awaken his reader to the fact that these miserable stories were unfolding, literally, right around the corner.

The injustice described in Tehrān-e Makhuf is very often gendered - indeed, it has been argued that the emancipation of women is the one overriding message of the novel. ${ }^{41}$ This injustice cuts across class and it manifests spatially. Moshfeq hails his heroine, Farrokh's beloved Mahin, for attaining reading skills and knowledge despite the fact that her evil father regrets allowing her to attend school and tries to dissuade her from reading foreign literature. Mahin is subject to social control: harakātam-rā taht-e nazar dārand, she writes in a secret letter to Farrokh, '... they are watching my every movement' ${ }^{42}$ In one scene, Farrokh is forced to communicate with Mahin across the wall surrounding her home; eventually, he breaks with all rules and physically abducts her. Moshfeq, in other words, put the restrictions on women's mobility on display as a socio-spatial manifestation of patriarchal norms.

In scenes from the brothel, Moshfeq gives plenty of space for some of the fallen women to tell their stories - of course, in Moshfeq's own romantic, naïve imagination of what such stories might be. The most prominent story is that of 'Effat: a noble woman who, due to the wickedness of her husband ends up in the red-light district. 
'Effat's story reveals to the reader what can happen in the dark underbelly of the city to those who are at the mercy of the stronger and unprotected by the state. Hence, we witness a drunk, violent Cossack forcing himself into the brothel; in the ensuing melee, Farrokh incidentally saves his rival, Siyavash, from the sabre. But when someone mentions involving the police, Farrokh dryly notes that 'the innocent and sinless are those first convicted in this city'. ${ }^{43}$

Yet, Dreadful Tehran also contains some spaces of respite. One such space is the mounds of earth or mud (tall-e khāk) that made up much of Tehran's city wall or moat (khandoq). Although these city limits have historically served as a sanctuary for outcasts, fugitives, gypsies and beggars, this is also where Farrokh escapes in his most excited or despairing moments, breathing in the cool night air as he watches the lights go out one by one across the city.

Another space of respite is, unsurprisingly, outside of the city. The idyllic slopes of the Shemiranat area north of Tehran are the backdrop of Farrokh's escape with his beloved. 'Let us go to the Shemiranat', he tells Mahin; 'the village people are superior to townsfolk in terms of morals and intentions'. ${ }^{44}$ The fresh mountain air, the simple joys of rural life and the forthright attitude of villagers are contrasted with the suffocating filth, pain and deceit of the city.

What appears as truly liberating, however, is the protagonist's ability to zigzag the city - sometimes defiant and in transgression, sometimes disillusioned and adrift, sometimes dreaming and excited. Different walking paces are presented as reflections of his changing mood and thoughts, even making him look like a lunatic to passers-by. By walking around the city, Farrokh is in fact mapping it for himself and for the urbanizing public, disalienating himself and the reader from a city that was fast 
becoming unmanageable and estranging. To borrow the words of Fredric Jameson, Farrokh's walks constituted 'the practical reconquest of a sense of place' ${ }^{45}$

This is, of course, a highly privileged position at a time when most Tehranis were highly restricted in their movements. Nonetheless, Moshfeq depicted the mobility in heroic terms: By using Farrokh as a people's detective or as a tour guide to a city corrupted to its core, the author could expose the addresses from which injustice emanated or materialized. With this technique, Moshfeq sought to outrage the urbanizing public.

\section{Sanitizing hearts and minds}

Tehrān-e Makhuf is not just about Tehran. Moshfeq's contribution to the urbanization of the Iranian public involved using urban sites and themes as conduits for broader issues and concerns of civilisation, nation and state. ${ }^{46}$

In the very first line of the novel, Moshfeq delivers a harsh, sarcastic comment on national pride. We are told that the date is Monday, the 17th of the month Sha 'ban, the year $133 \mathrm{X}^{47}$; and the reader is invited to 'Tehran, capital of the country Iran; the same country that prides itself to the world in having an ancient civilization and great, renown and honourable poets... ${ }^{48}$ And yet, the city we meet is not a place of civilized life in which the nation can take pride. In fact, Chaleh Meydan is described by Moshfeq as Tehran's version of Cour des Miracles 'but several hundreds of years ago'.49

Moshfeq thus positioned himself with privileged knowledge about Europe as he likened Tehran to Paris prior to Haussmannization. Put differently, he used the state of the built environment in the capital to place Iran at least two centuries behind France on the trajectory of modernity. In this, there was an implicit demand and aspiration: not 
just to let Tehran undergo the same drastic socio-spatial reconstruction Paris underwent at the hand of Baron Georges-Eugène Haussmann in the 1850s to 1870s; but rather to Haussmannize Iranian society on all levels.

As such, Moshfeq's descriptions of Tehran as a place with dust and dirt in the air, with badly lit streets full of potholes, with a dearth of public transport, with an understaffed and incompetent municipality and with whole areas of the city marked by squalor - all these descriptions are tools to embarrass or enrage the novel's public. The critique is a call to arms to develop and defend Iran by improving and modernising its public spaces and through that, its national character and international standing.

Sometimes these calls appear blatant, naïve or abrupt, when the narrator switches to orator. One example is from Moshfeq's description of one of the antagonists, 'Ali Ashraf Khan - a crooked state official who has sold his wife off to prostitution to secure his position while succumbing to opium addiction. Moshfeq zooms in on 'Ali Ashraf Khan lurking around in the bazaar, waiting for a chance to sneak into a secretive building. The author switches to the paternalistic voice of a concerned nation:

Entering that house in those days would cause anyone embarrassment and shame ... because this was an opium den, and going to such a place to smoke opium and shireh $^{50}$ was considered even more unbecoming than it is today; because it was in such places that some members of the Iranian people would go to give away their honour and ambition. ${ }^{51}$ Just as prostitution, drug abuse is seen as a threat to the city, the nation, indeed to 'the health of the Iranian race' ${ }^{52}$ the depravity circulating in the veins of Tehran is 
corrupting the nation body from within, whether the plagues killing the poor or the selfinflicted diseases keeping the elites awake at night.

With scathing critique, Moshfeq makes it clear that the elites are ill equipped or unwilling to protect society from threat. In Tehran's plush gardens, we find spoiled aristocrats eating $p \overline{a l u d e h}$ sorbet while mindlessly name-dropping, with the wrong pronunciation, Western figures of importance ('...Lord Curzon, Karl Marx, Bismarck... ${ }^{53}$ ). When Moshfeq lets us into the Royal Club, we witness the country's power-holders plotting election fraud ${ }^{54}$ in order to defend themselves against their subalterns ( $r a$ 'iyat) and force the commoners to concentrate on agriculture rather than hezb-bāzi or '[political] party games'. ${ }^{55}$ The Royal Club clientele is even referring to Darwin (as well as medieval Persian poet $\mathrm{Sa}{ }^{\text {'di) }}$ to formulate a crude social determinism with which to legitimize their arbitrary rule.

In the 'second class', Moshfeq sarcastically introduces us to people with different 'interests and tastes', ranging from

... the Western-mimicking [farangi-ma' $\bar{a} b]$ to those who display great deference for Arabs; some who see it as imperative to employ European words and some who consider it a religious command to over-pronounce Arabic words; some who gather people around themselves on the pretext of promoting the new civilization and some who fool the simpletons by appealing to the protection and consolidation of religious customs ...

Here, Moshfeq revealed his opinions about, on the one hand, self-proclaimed modernists infatuated with everything Western and fantasizing about a 'new civilization' in Iran; and, on the other hand, the regressive, conservative religious elites 
and their admiration for the supposedly inferior culture of Arabs. In passages such as this, the chauvinism with which secular Iranian nationalists sought to 'dislocate' themselves from the Arab, Islamic world in order to 'return' Iran to some imagined Aryan, pre-Islamic civilisation is clear. ${ }^{57}$

But Moshfeq also derides his potential allies in the supposedly progressive new middle class as ignorant, self-interested and unprincipled. This class, it turns out, is not the saviour of Tehran or Iran. The middle-class youth is described as joojeh-fokoli, 'baby dandies', drifting around in the city, imagining themselves to be one thing or the other, always opportunistic and wavering in their politics. ${ }^{58}$ Farrokh is physically repulsed by their 'fun and recreation', their laughing and showing off on a public holiday. ${ }^{59}$

Poor people are not spared critique either. The protagonist, for example, is surprised to see Javad turn up on time for a planned rendezvous, since he does not expect from his 'compatriots such a punctuality, particularly not from someone from the downtown quarters'. ${ }^{60}$ Again, this is a standard critique from modernist intelligentsia of the time: that Iranians are unreliable, lazy and in need of disciplining.

In other words, Moshfeq used particular techniques in his attempt to summon a particular national public through representations of urban society. With the city as frame and medium, he pushed a demand for societal Haussmannization: Just as the streets and backstreets, bazaars and slums of Tehran should be sanitized or bulldozed to pave way for the new, so should the elites, the masses and society at large be cleansed, reformed and reconstructed.

\section{When everything melts}


The project of societal Hausmannization, however, was not a fully developed political program, and it left Tehrān-e Makhuf riddled with contradictions.

Farrokh seems caught in the paradoxes de jour. On the one hand, he is wary of change, the erosion of supposedly authentic elites and the emergence of new, corrupt ones; and yet on the other hand, change is happening too late, too slow. Tehran is at once already urbanized and modernizing but clearly not urban and modern enough. There is no civitas in the urbs and that is why a proper, modern notion of citizenship and understanding of democracy has yet to emerge. As Yahya Aryanpour remarks, Moshfeq did not consider himself and his peers capable of ushering in the reformation needed. $^{61}$

This leaves Farrokh uneasily suspended between stability and change, critical of both the ancien régime and the nouveaux-riches, at once pessimistic about the new Iran that is emerging and yet wanting to rush into the future. Farrokh is, in the words of Marshall Berman, 'both revolutionary and conservative: alive to new possibilities for experience and adventure, frightened by the nihilistic depths to which so many modern adventures lead, longing to create and hold on to something real even as everything melts' ${ }^{62}$ Ultimately, these paradoxes lead to a sense of defeatism and a perpetual unease and discontent with the contemporary world.

Without placing unfair expectations on a 20 -year old in 1922 , it is also clear that through Farrokh's actions, Moshfeq strove to turn traditional patriarchal notions of shame and honour (sharm, gheyrat) and of male heroism (javānmardi) into 'modern' virtues - not to destroy them. Moshfeq wanted to be a voice for women, but on his terms and to project his own eroticized fantasies about fallen women. It appears then 
that not even in his most important political message was Moshfeq whole-heartedly radical.

What tempered young Moshfeq's radicalism? What made Farrokh waver? We will return to this question but before that, I will look closer at the circumstances surrounding the production of Tehrān-e Makhuf.

\section{Assembling a propellant}

I will attempt to draw together two interrelated aspects of Moshfeq's life and work in the time leading up to the publication of Tehrān-e Makhuf: his experience in the city and his sources of inspiration. The aim is to understand what equipped Moshfeq to assemble a distinct style of social critique that would become such a game changer for Iranian literature. There are not many sources to consult for this purpose other than Moshfeq's 1971 two-volume auto-biography Ruzegār va andisheh-hā ('Life and Thoughts'), and here I will focus only on the years prior to and including 1922.

The Tehran that Moshfeq describes in his memoirs is very similar to that of the novel: a grimy, underdeveloped city marred by intermittent famine and outbreaks of typhus and Spanish flu, where authorities are incapable of apprehending criminals. ${ }^{63} \mathrm{~A}$ number of historical events unsettle the Tehran of his childhood and youth: the 1908 bombardment of the parliament and demonstrations at the British Legation, both connected to the Constitutional Revolution; the debates surrounding the 1911 appointment of the US lawyer Morgan Shuster to financial advisor for the Iranian state; and the protests against the Anglo-Iranian Treaty of 1919. Above all, the shock of the British and Russian military campaigns on Iranian soil during the First World War and the constant threat of foreign intervention loom large in Moshfeq's recollections. 
However, Moshfeq also recalls Tehran with fondness: the beautiful city gates, the lush gardens, Lalehzar Street with its teeming street life. He describes Ramadan celebrations when people would fill the squares and streets around Sepahsalar Mosque and Negarestan Garden ${ }^{64}$ and he recalls a gārden-pārti, a sort of interim amusement park with lottery, shooting gallery and music performances. He also remembers sitting and reading books in cafés around Jennat-e Golshan Street.

It is in his teenage years that Moshfeq finds great pleasure in a new social phenomenon: collective walking tours across Tehran. Every Friday, he explains, they would walk all the way from the city centre to the villages north of Tehran. They would wear 'white shirts and espadrilles', sing songs, recite poetry and discuss various political and cultural issues. Sometimes they would sleep over in gardens and huts or hike through the mountains and forests outside of the city. Moshfeq explains:

Apart from its beneficial effect on our health, these walks were particularly joyful to me because I found myself among like-minded friends, and all were pained and concerned with the really lamentable social conditions of the day. ${ }^{65}$

This new social phenomenon, then, relocated what was usually an in-door, semi-private practice into the public realm. Moshfeq and his peers would indeed 'hang out' in public spaces - outside the guesthouses Paris and Hôtel de France near Tupkhaneh Square, on the staircases in front of a French bookstore, under the archway of Grand Hotel, and in cafés, looking at women strolling on Lalehzar Street - again, new upper middle-class practices that differed from those of earlier generations and their modes of recreation. Just as sale and consumption moved from the covered, labyrinthine bazaars into the streets and avenues, so did socialization. Being 'seen' in certain places was no longer 
stigmatized for young men of the elite. Public space, in short, became a site for a particular kind of consociation among self-proclaimed progressives that was tied directly together with their politics.

These new practices mirrored new directions in arts and literature. Tehrān-e Makhuf appeared in the middle of a seismic shift foreshadowed by pioneering poets such as Mirzadeh 'Eshqi, Iraj Mirza, 'Aref Qazvini and 'Abol-Qasem Lahuti with their sharp political satire, social critique and patriotic messages, all of which clearly influenced Moshfeq. ${ }^{66}$ Although Moshfeq's style of writing is not qualitatively comparable to that of contemporary avant-garde literati such as Mohammad-'Ali Jamalzadeh or Nima Yushij, Tehrān-e Makhuf was nonetheless part of the same endeavour to simplify, deformalize and democratize language and literature.

In this respect, Moshfeq was more tangibly inspired by two other genres: popular tales and journalism. He mentions the following as among his favourite young adulthood reading: Amir Arsalān, a popular romance originally told to Naser-od-Din Shah by his Chief Story-Teller (naqqāl-bāshi) and later recorded by the shah's daughter; Eskandar-nämeh, which implies one of several versions of old popular tales about Alexander the Great; and Hossein-e Kord, another popular tale dating back to the Safavid era and featuring medieval knights ( 'ayyārān). The inspiration from these stories and traditions is clear. With its episodic style and focus on a rogue protagonist, Tehrān-e Makhuf can be situated within a picaresque genre. ${ }^{67}$

In the mid-1910s, young Moshfeq found an interest in newspapers. He was particularly fond of old issues of Sur-e Esräfil from the Constitutional Revolution era, edited by the brilliant linguist and lampoonist 'Ali-Akbar Dehkhoda, as well as the satirical newspaper Nasim-e Shomāl. In his late teens, Moshfeq read the newspapers 
$R a$ 'd, Irān and 'Asr-e Jadid, representing a range of political views. These newspapers seem to have played a particularly important role, not only in format and language but also in terms of content.

$R a$ ' $d$ was published from 1913 by the reformist journalist Seyyed Zia'-od-Din Tabataba'i up until February 1921 when Tabataba'i became Prime Minister following Reza Khan's coup. In his memoirs, Moshfeq mentions the attention Tabataba'i paid to municipal matters from the beginning of his premiership, including the appointment of a regular contributor to $R a^{\prime} d$, the Ottoman-Armenian Gaspar Epekiyan, as mayor of Tehran.

Under Epekiyan, the US government extended a loan to Tehran Municipality and two American advisors were deployed to oversee a fundamental restructuring. Power lines were established and lights put up in main streets such as Amiriyeh, Lalehzar and Eslambul while Cheragh-Barq Avenue was asphalted, businesses forced to change from 'foreign' shop signs to Persian ones, restaurants, baths and barbershops were subjected to public health inspections and a new, majestic building for the Municipality was built. ${ }^{68}$ Moshfeq recognizes some of these changes in his memoirs ${ }^{69}$ and apart from the fact that they both frequented Tehran's new theatre circles there is reason to surmise that Epekiyan's writings and activities trained Moshfeq's eye for urban dimensions of modernization.

Apart from the journalistic and didactic tone we so often hear in Tehrān-e Makhuf, Moshfeq also took another crucial inspiration from late Qajar newspapers: serialized novels. Moshfeq most likely read some of the dāstān-e 'ebrat (morality tales), exemplified by the hugely popular 'Arusi-ye Mehrangiz ('Mehrangiz's Wedding') by Yahya Mirza Eskandari, which was published in the newspaper Irān-e Now in 1910. 
Morality tales such as Eskandari's 'were often presented in the form of romantic tales with tragic endings ${ }^{70}$ and depicted 'heartless men [who] exploited the longings of naïve women for romance to illicit sexual ends' ${ }^{71}$ Stories of 'a mischievous urban fukuli' (dandy) causing the downfall of a good woman, who in turn symbolized the nation falling prey to 'opportunistic political youngsters', Afsaneh Najmabadi explains, traces its genealogy back to these moral tales. ${ }^{72}$ Such stories, of course, are also very prominent in Tehrān-e Makhuf-one could even argue that Tehrān-e Makhuf is an extension or perhaps recalibration of the dāstān-e 'ebrat genre.

Moshfeq pays considerable homage in his memoirs to the circles in Tehran pioneering modern drama and music. He describes his first experience with theatre, a Molière piece in Grand Hotel on Lalehzar Street; but also how he was impressed with a ma 'reke (circus or fair) staged by a visiting troupe from Russia. Indeed, the Russian and Caucasian influence is palpable in Tehrān-e Makhuf. Moshfeq mentions watching Peter Chardynin's 1917 U Kamina ('By the Fireplace'). ${ }^{73}$ This silent movie, a blockbuster in Tsarist Russia on the eve of revolution, features Vera Kholodnaya in the role of an aristocratic woman who suffers a horrible destiny. Although he does not mention Russian literature in his own memoirs, it is very likely that the socially critical literature that emerged after the 1905-07 Revolution in Russia inspired Moshfeq. ${ }^{74}$ Moshfeq does mention the impact of seeing 'Caucasian actors' performing the celebrated operettas Mashdi 'Ebād (1911) and Arshin Mal Alan (1913) by the famous Azerbaijani playwright Uzeyir Hajibeyov who used drama, romance and comedy to criticize traditional mores.

After joining a circle of playwrights around Mirza Seyyed 'Ali Khan Nasr (who had founded Iran's first modern theatre in 1918), Moshfeq produced a play based on his 
own translation of Jean Rancine's absurd 1668 comedy Les Plaideurs ('The Litigants'). Later, Moshfeq became acquainted with, and highly influenced by, Reza Kamal ('Shahrzad') and Hassan Moqaddam, two legendary dramatists. Moshfeq also assisted in adaptations of Armenian plays for the Iranian stage.

To facilitate a keen interest in European literature, Moshfeq explains how an employee at Tehran Post Office with contacts in Paris helped him procure French novels that he read with the aid of dictionaries. ${ }^{75}$ Moshfeq mentions a general penchant for 'emotional' music and writing from Europe; specifically, he alludes to Gustave Flaubert, Victor Hugo and Boccacio's Decameron. ${ }^{76}$ But apart from these, Moshfeq was also acquainted with translated European classics that had been serialized in Iranian newspapers since the 1850 s, including masterpieces by Alexandre Dumas. Indeed, as Kubickova has argued, 'the romantic story of [Farrokh] often recalls whole passages of Dumas' Count of Monte Christo' ${ }^{77}$

Moshfeq himself, however, emphasizes Triboulet, a work by the Corsican anarchist, journalist and novelist Michel Zévaco, who is famous for cloak and dagger tales that continue to enjoy a readership in Iran today. Triboulet was serialized in 'Asr-e Jadid, which may also have carried works by another source of inspiration mentioned by Moshfeq, namely the Lebanese communist and author Nicola Haddad. The latter's numerous novels all had elements of romance, social critique and moralization reminiscent of Moshfeq's work - and many of them highlighted women's plight. ${ }^{78}$

In a recent article, Manizheh Abdollahi and Ehya Amalsaleh discuss the issue of translated French roman-feuilletons in Iranian newspapers and argue that Moshfeq may have been influenced by that epic of urban fiction, Les Mystères de Paris (published 1842-3) by Eugène Sue - or at least by the genre of 'city mysteries' that Sue's work 
gave birth to. Indeed, Sue's social realism, melodramatic storyline and particular attention to urban blight, as well as his use of an upper-class protagonist who can fraternize with the lower classes and, in the process, expose the dangerous spaces of the city are all strikingly similar to what we see in Tehrān-e Makhuf. I will return in the final section of this article to why this is particularly interesting.

It is clear, then, that Moshfeq was exposed to theatre and literature that traversed regions and borders thanks to itinerant performers, transnational networks of intellectuals, global mail systems, translators and the editors of serialized fiction catering for a growing reading public. Through the sources of inspiration made available by these networks and actors, Moshfeq helped create a genre with Tehrān-e Makhuf that can be described as an urbanized, recalibrated picaresque drawing on traditional Iranian narratives as well as European and Caucasian theatre, cinema and literature and newer Iranian poetry and prose, fiction and journalism. This combination allowed Moshfeq to introduce realistic and socially critical descriptions of urban society while at the same time retaining the idealistic-romantic registers of traditional epics. This combination turned Tehrān-e Makhuf into a game-changer.

The assemblage of political, social and cultural products, networks and processes that came together on the streets of Tehran and in the thoughts of Moshfeq in the 1910s and early 1920s, then, is part of the intertwinement in history that Tehrān-e Makhuf embodies. The practices of urban cultural consumption and production reading folk tales, newspaper columns and serialized fiction, watching silent movies, circus and drama, walking across the city, hanging out in public places, frequenting intellectual and artistic circles and discussing politics - are all connected in the urbanizing Iranian public. 


\section{Contradictory radicalism}

In this final section, I will discuss Moshfeq's politics. The overriding question is: what can the urbanizing public seen through Tehrān-e Makhuf and Moshfeq's memoirs tell us about a crucial transition in Iran's political and intellectual history?

As we have seen, Tehrān-e Makhuf is laden with contradiction. The novel exposes social inequality and injustice, and as such, it contains numerous hints at the narrator's (and the author's) progressive leanings. Only rarely, however, does the socially critical observations turn into more pronounced political statements. During his exposé of the Royal Club, for example, Moshfeq steps out of the narrative to criticize the anti-democratic worldview of the elite, in the process revealing what appears as an almost socialist worldview. ${ }^{79}$

In the sequel to Tehrān-e Makhuf, Moshfeq explains that the protagonist has joined a band of revolutionaries. These are the Jangalis under Mirza Kuchek Khan who rebelled from the middle of the 1910 s against the central government from their forest strongholds in Gilan Province. Crucially, however, Farrokh shifts sides, joining instead the Cossack Brigade, which was in the process of crushing the Jangali rebellion. This was not mere opportunism, Moshfeq assures the reader; in fact, Farrokh was disillusioned by events in Russia, where Bolsheviks as rulers had betrayed their revolution. ${ }^{80}$ This also seems to legitimize the fact that in the sequel, Farrokh settles for mere personal revenge rather than a crusade for social justice.

From his memoirs, we understand that Moshfeq himself was radicalized during burst of political activism following the revelation of the contents of the 1919 AngloIranian Treaty, including demonstrations, sit-ins and the publication of shabnāmeh 
(underground pamphlets). He also describes the pervasive sense of fear in Tehran during the winter of $1919-20^{81}$ - the same winter that he wrote what would become the first two chapters of Tehrān-e Makhuf. At that point, negotiations between the Jangalis, the British forces and the central government were breaking down and soon after, the Bolshevik faction of the Jangalis declared a short-lived Soviet Republic in Gilan.

The anxiety of that time, it seems, also carried within it the authoritarian seeds of 'enlightened despotism': 82 the idea that turmoil, bad leadership and weak institutions combined with society's lack of progress, education and enlightenment meant that Iran was not ready for democracy. The Constitutional Revolution had given way to disillusion and 'a strong man' was needed to put Iran together again. Moshfeq thus applauds the crushing of outlaws and rebels, including the Jangalis. Although he criticizes the state's wanton use of violence - also indicated in passages of Tehrān-e Makhuf - there is no doubt that by the time of the 1921 coup, Moshfeq was thoroughly in favour of Reza Khan's strong man policy.

This support is obviously tied to Moshfeq's desire for rapid top-down modernisation. Moshfeq saw Iranian society as backwards, its elites full of self-deceit and its public religious rituals deplorable. ${ }^{83}$ This self-critique, in turn, fed on an infatuation with progress in Europe:

Reading or hearing about matters pertaining to Europe and the everyday life of people in those countries by watching cinema movies or browsing illustrated journals that I came across, I came to discover scenes of the lives of Europeans that made me depressed and gave me a feeling of inferiority and shame - [a feeling] which I undoubtedly shared with a number of my compatriots! $!^{84}$ 
Moshfeq believed Iran's backwardness was caused historically by the constant intrusion of foreign powers at a lower stage of civilisation than the Iranian, from Alexander the Great to the so-called 'Arab' invasion, the Mongols and Tamerlane. The accumulated effect of these invasions and immigrations was 'atavism', which was mirrored in the fundamental instability of social and political institutions. ${ }^{85}$ As we shall see, this chauvinist nationalism would soon replace any inclination Moshfeq might have had towards socialism.

Moshfeq tells us that sometime in the summer of 1922, he spent 13 days and nights in a row writing what became Tehrān-e Makhuf:

... I took the pen in my hand and influenced by my surroundings and by all the hardships that others had endured, and of which I had seen, heard or experienced a modicum on my own body, up until that hour, I began to write. $^{86}$

Despite choosing an ominous title for his work, Moshfeq states that he 'nourished a naïve hope and wish that this story will announce the end of a dark time in our lives, and that, in the end, our dear Iran will return to its glorious and dazzling destiny ${ }^{87}$. Furthermore, he claims that although none of the stories were based on reality, 'numerous' people have nonetheless claimed so; 'it appeared that I had in fact taken the worries of all compatriots down on paper', ${ }^{88}$ Moshfeq writes, and for this reason, he did not pay much attention to the objection of peers that parts of the story seemed unrealistic: 'I understood the taste of my compatriots better' ${ }^{89}$. In other words, Moshfeq was already writing for a public. The question was: how was he going to reach it?

Moshfeq explains in his memoirs that he opted for serialization simply because he could not afford to have Tehrān-e Makhuf published as a novel. At the same time, 
however, Tehrān-e Makhuf also appears remarkably suited for the purpose of serialization. Claus Pedersen, for example, points out that 'cliff-hangers' and similar techniques indicate an eye for newspaper sales. ${ }^{90}$ Although we do not have any precise information about the readership of Setāre-ye Irān, we can safely surmise it was primarily made up of the urban upper middle classes.

Hence, in Setāre-ye Irān, Moshfeq already had a public waiting that was often addressed in the paternalistic voice and was used to serialized fiction. ${ }^{91}$ The novel itself was meant to be a vehicle of modernisation and enlightenment; a newspaper that branded itself as exactly that was a perfect venue. Furthermore, the bourgeois values expressed in Setāre-ye Irān were congruent with what would soon characterize Moshfeq's politics: it was generally pro-British, faithfully nationalistic and staunchly anti-socialist. Indeed, at the same time as it was publishing Tehrān-e Makhuf, the newspaper also brought the serialized memoirs of the Armenian Grigor Eghikian, which detailed 'Bolshevik dirty work in Gilan during the Republic'. ${ }^{92}$ Although he was later to be persecuted and tortured by the government, the owner and editor of Setāre-ye Irān was a strong advocate of Reza Khan at the time of Tehrān-e Makhuf's publication. In other words, the venue for the novel seems suited for the contradictory balancing act between progressive egalitarianism and anti-socialist reaction that creeps out between the lines in Tehrān-e Makhuf.

Beyond the genre similarities between Tehrān-e Makhuf and works such as Eugène Sue's Les Mystères de Paris mentioned above, there are also interesting potentials for comparison of ideology. In their The Holy Family, Karl Marx and Friedrich Engels used Sue's hugely successful work in their scathing attack on the Young Hegelians. Like the Young Hegelians, Marx and Engels argued, Sue was out of 
touch with social reality, stuck in a medieval consciousness - a dandy socialist who ended up reproducing the inequalities he presumable wanted to combat. ${ }^{93}$ By laying bare the inequalities of the city, Sue had not been able to produce a different and more just vision of future society. At odds with this critique stands the fact that Les Mystères de Paris actually contributed greatly to the French Revolution of 1848 and that Sue was a progressive politician. ${ }^{94}$ However, while Umberto Eco's studies of Les Mystères de Paris shows that Marx and Engel's critique was perhaps unnecessarily unkind, and while he rejects the existence of a link between the roman-feuilleton as format and conservatism (or reformism) as ideology, Eco nonetheless recognizes that [p]eace, in the commercial novel, takes the form of reassurance by reiteration of what the reader expects, and when expressed in ideological terms it assumes the aspect of a reform which changes something so that everything will remain the same. ${ }^{95}$

This could also be said of Tehrān-e Makhuf. Instead of championing actual change, Moshfeq resigned himself to what Homa Katouzian calls a 'fashionable modern middleclass moralizing, ${ }^{96}$. A harsh verdict, then, would be that Tehrān-e Makhuf was just poverty tourism: elite entertainment masquerading as social critique.

However, despite these resemblances, there are also some quite important and obvious differences that limit the comparison: Moshfeq was not writing on the eve of a Paris Commune; if anything, he was writing in its painful aftermath, when the outburst of progressive activism in the spheres of parliament, municipality, political parties, oppositionist clubs and women's rights circles that followed the Constitutional Revolution had been quashed and quelled by authoritarian clampdown and reaction. More importantly, Iran was at the time the target of several foreign power schemes and 
in a state resembling civil war. In Moshfeq's memoirs, the fear of foreign domination and revolutionary chaos are present on every page. It is also not insignificant that one of the foreign powers most active on Iranian soil at the time was the Soviet Union.

In the end, the sense of fear did not dissipate with the 1921 coup. In fact, Moshfeq remembers the intimidating sight of a drunk Cossack riding through Lalehzar Street with his sabre raised - a scene echoed in Tehrān-e Makhuf. He also complains that Tabataba'i's government was just as bad as the one it replaced. And by the time he finished Tehrān-e Makhuf, Moshfeq had seen another two prime ministers come and go while Reza Khan was busy crushing rebellions across the country.

If Moshfeq had been something of a dandy socialist when he wrote Tehrān-e Makhuf, just two years later he was in the Weimar Republic, penning praise for Mussolini ${ }^{97}$ and calling for an 'enlightened dictator' at home. ${ }^{98}$ When he returned in 1926, he joined the cadres of apparatchiks under Reza Shah who were busy institutionalizing military-style governance, promoting Persian-centric nationalism and pushing through reforms and large-scale change - including at least some of the spatial transformation of Tehran that Moshfeq and his peers had dreamt of. ${ }^{99}$

\section{Conclusion}

The city, I have argued in this article, is right there in the title and all over the pages of Tehrān-e Makhuf for a reason; and I believe previous studies have neglected this specific reason, i.e. that Tehrān-e Makhuf can be seen as a specifically urban product. With this reading, I have aimed to demonstrate that we cannot properly understand a cultural product without analysing the material conditions and geographical context of its production. 
I have drawn inspiration from Schayegh's heuristic umbrella of 'transpatialization' to argue that the connections that led to the production of Tehrān-e Makhuf were not random: they constituted a socio-spatial intertwinement of tradition and innovation, local, regional and foreign arts and literature, perceptions of the built environment in Tehran, new social, artistic and political practices in the city as well as of Iranian national politics. Spawned by this intertwinement, Tehrān-e Makhuf was at once a reflection of and a propellant for the urbanization of the Iranian public.

As Schayegh has argued, we should not assign primacy, in history writing, to one process (urbanization, globalization, state-building) in isolation from others; rather, we should study their intertwinements. ${ }^{100}$ In those historical intertwinements, there are certain propellants that can change the pace and nature of change seemingly over-night. Tehrān-e Makhuf was one such propellant: it constituted if not a paradigm shift in Iranian literature then at least a significant refocusing of frame.

In order to understand this frame-shift, I have employed the methods of urban cultural studies to show how Moshfeq brought the city to view as both subject matter and contextual frame. Specifically, I have explored this overlapping of text and context in three moves:

Firstly, I have shown how in Tehrān-e Makhuf, Moshfeq employed at least three new techniques: mapping out and laying bare the class structure of Tehran through representations of urban life; addressing injustice, fear, corruption, crime and oppression by 'giving them an address'; and using the urban as a canvas for painting a broader critique of culture, society and state. With each of these three techniques, Moshfeq aimed at making his public outraged and concerned - with the hope that this could lead to demands for wide-ranging reform. 
Secondly, I have placed the production of an urbanizing public in Tehrān-e Makhuf within two contexts: the emergence of new social and spatial practices in young Moshfeq's Tehran; and the intertwinement of local, regional and global trends, networks, ideas and products in Moshfeq's milieu and network. I have argued that the particular kind of social critique seen in Tehrān-e Makhuf was produced by this unique assemblage of, on the one hand, artistic, cultural and intellectual sources of inspiration and, on the other hand, new social and political practices.

Thirdly, I have placed Moshfeq's work and politics within its historical context. I have used Tehrān-e Makhuf as an example of the shift away from the ideals of freedom and pluralism embedded in the Constitutional Revolution towards the authoritarian and pro-Westernization discourse of the Pahlavi period. With its unresolved stance on the issue of social equality and its contradictory radicalism, Tehrān-e Makhuf is emblematic of this shift.

I hope these arguments will be challenged or inspire further study of the intertwinement of cities, culture, publics and broader processes on national, regional and global scales.

\section{Notes.}

\footnotetext{
${ }^{1}$ Tehrān-e Makhuf originally appeared as a serialized novel in 1922 and then as a two-volume book in 1923. The first volume of the sequel Yādegār-e Yek Shab was published in $1923 \mathrm{i}$ Berlin and the second volume in 1924 in Tehran. For the purpose of this article, I have relied on: S. M. M. Kazemi, Tehrān-e Makhuf(Tehran: Ebn-e Sina, 1961 [1923]).

${ }^{2}$ E.g. H. Mirabedini, 'MOSHFEQ-e KAZEMI, SAYYED MORTAZA', Encyclopaedia Iranica, online edition (New York, 1996- [2011]); C. V. Pedersen, The Rise of the Persian Novel. From the Constitutional Revolution to Rezâ Shâh 1910-1927 (Wiesbaden: Harrasowitz Verlag, 2016), p. 110.
} 
${ }^{3}$ The research presented here began as a paper for the Association of Iranian Studies conference in Vienna, August 2016. Thanks to Camron Amin for chairing and commenting. In December 2017, I presented a different take for the Offentlighedskredsen at the University of Copenhagen and I thank the circle for their comments. All translations from Persian by this author.

${ }^{4}$ C. Schayegh, The Middle East and the Making of the Modern World (Harvard: Harvard University Press, 2017), 336.

${ }^{5}$ C. Schayegh, 'Transpatialization: A New Look at the Old Question of How the Modern World Was Formed', Harvard University Press Blog, $6^{\text {th }}$ November (2017).

${ }^{6}$ The most in-depth analysis of the novel is in Pedersen, Persian Novel, Chapter 5.a. Other interesting discussions can be found in: A. M. Aloob, The Persian Social Novel from 1900 to 1941, PhD Dissertation (Ann Arbor: University of Michigan, 1988); Y. Aryanpour, Az sabā tā nimāa (tārikh-e 150 sāl-e adab-e färsi), Vol. II, 5th Ed. (Tehran: Zavvar, 1994), 257-63; R. Haag-Higuchi, 'Historical Events in Persian Novels', Oriente Moderno, Vol. 22 (2003), 131-1444; S. Meskub, Dāstān-e adabiyāt va sar-gozasht-e ejtemā'; 3rd Ed. (Tehran: Farzan, 2006), 134-150.

${ }^{7}$ See: S. Aliyari \& L. Nowhi-Tehrani, 'Rābete-ye mizān-e tavānmandi va now'e monāsebāt-e jensiyatiye shakhsiyat-e asli-ye zan dar romān-e Tehrān-e Makhuf (Mortazā Moshfeq-e Kāzemi)', Jāme 'ehshenāsi-ye honar va adabiyāt, Vol. 4 (2013), 21-38; E. Neqabi \& K. Qorbani-Juybar, 'Neshāne-shenāsiye avvalin romān-e ejtemā'i-ye irān', Majalle-ye dāneshkade-ye adabiyāt va 'olum-e ensāni, Vol. 18 (2010), 193-211; S. Parastesh \& S. M. Gazar, 'Bāz-namā'i-ye fazā-hā-ye shahri-ye tehrān dar romān-hāye dowre-ye rezā pahlavi', Jāme 'eh-shenāsi-ye honar va adabiyāt, Vol. 3 (2011), 105-132; M. Razaqpur, 'Naqd-e jāme'eh-shenākhti-ye tehrān-e makhuf', Matn-e pazhuhi-ye adabi, Vol. 35 (2008), 27-53.

${ }^{8}$ For the purpose of this article, I understand public in a narrow sense: 'the kind of public that comes into being only in relation to texts and their circulation', to quote M. Warner, 'Publics and Counterpublics', Public Culture, Vol. 14 (2002), 50. The limits to the extended understanding of a public as öffentlichkeit and as 'public sphere' in the Habermasian sense has been subject to many interesting critiques, e.g.: A. Salvatore \& M. Levine (Eds.), Religion, Social Practice, and Contested Hegemonies (New York: Palgrave Macmillan, 2005); B. de S. Santos, 'Public Sphere and Epistemologies of the South', Africa Development, Vol. 37 (2012), 43-67; S. Shami (Ed.): Publics, Politics and Participation: Locating the Public Sphere in the Middle East and North Africa (New York: Social Science Research Council, 2009).

${ }^{9}$ B. Fraser, 'Inaugural editorial: Urban cultural studies - a manifesto (Part One)', Journal of Urban Cultural Studies, Vol. 1 (2014); B. Fraser, Toward an Urban Cultural Studies: Henri Lefebvre and the Humanities (New York: Palgrave Macmillan, 2015). More generally, a range of interesting and inspiring works have emerged at the intersection of literary studies, social science and critical urban studies. For overviews, see: J. Finch, 'Modern Urban Theory and the Study of Literature' in J. Tambling (Ed.), The Palgrave Handbook of Literature and the City (New York: Palgrave Macmillan, 2016).

${ }^{10}$ Fraser, 'Inaugural', 3.

${ }^{11}$ Fraser, Toward, 20. 
${ }^{12}$ In terms of method, I have located places mentioned on maps of Tehran; studied these places through primary and secondary sources; and finally, I have contextualized the novel's representations of Tehran with Moshfeq's autobiography and by studying his sources of inspiration. For general knowledge of Tehran at the time I have employed: S. Nafisi, Goft-o-gu-ye khānevādegi darbāre-ye tehrān-e qadim (Tehran: Bongah-e Tarjomeh va Nashr-e Ketab, 1974); J. Shahri, Tehrān-e qadim, $3^{\text {rd }}$ Ed. (Tehran: Maherat, 1978 [2002]).

${ }^{13}$ A. Wigelsworth, Rewriting Les Mystères de Paris: The Mystères Urbains and the Palimpsest (Cambridge \& Oxon: Modern Humanities Research Association \& Routledge, 2016), 1.

${ }^{14}$ A notable exception is S. Cronin, Soldiers, Shahs and Subalterns in Iran: Opposition, Protest and Revolt, 1921-1941 (New York: Palgrave, 2010), Chapters 1-4.

${ }^{15}$ Cronin, Soldiers, 6.

${ }^{16}$ S. M. M. Kazemi, Ruzegār va andisheh-hā (Tehran: Enteshārāt-e ‘Ebn-e Sinā, 1971), 40.

${ }^{17}$ Ibid.

${ }^{18}$ Mirabedini, 'MOSHFEQ-e'.

${ }^{19}$ Pedersen, Persian Novel, 111.

${ }^{20}$ Kazemi, Ruzegā $r, 148$.

${ }^{21}$ This name - along with several others - is abbreviated, leaving the reader to guess what the letter stands for (F for Fahim, K for Kamran?).

${ }^{22}$ See: A. Khatam, Tehran Urban Reforms Between Two Revolutions, PhD dissertation (Toronto: York University, 2015), Chapter 2.

${ }^{23}$ Warner, Publics and Counterpublics.

${ }^{24}$ Kazemi, Tehrān, 261.

${ }^{25}$ Ibid., 261-62.

${ }^{26}$ Ibid., 5 .

${ }^{27}$ Ibid., 6 .

${ }^{28}$ Ibid., 6 .

${ }^{29}$ Mirabedini, 'MOSHFEQ-e'.

${ }^{30}$ Kazemi, Tehrān, 26.

${ }^{31}$ Ibid., 10.

${ }^{32}$ Ibid., 120.

${ }^{33}$ Ibid., 249.

${ }^{34}$ Ibid., 37-8.

${ }^{35}$ Ibid., 278.

${ }^{36}$ Ibid., 250-1.

${ }^{37}$ Named after Conte Monte Forte, an Italian officer invited to Iran in 1879 to establish a modern police force in Tehran.

${ }^{38}$ Kazemi, Tehrān, 162-3.

${ }^{39}$ Ibid., 245. 
${ }^{40}$ Ibid., 303.

${ }^{41}$ Pedersen: $127-8$.

${ }^{42}$ Kazemi, Tehrān, 110.

${ }^{43}$ Ibid., 97.

${ }^{44}$ Ibid., 182.

${ }^{45}$ F. Jameson, Postmodernism, or, the Cultural Logic of Late Capitalism (London/New York: Verso, 1991), 51.

${ }^{46}$ This is a point also recognized in A. Gheissari, Iranian Intellectuals in the Twentieth Century (Austin: University of Texas Press, 1997), 59.

${ }^{47}$ The precise date is censored for unknown reasons. We know that Moshfeq wrote the first two chapters sometime during the winter 1919/1920 before finishing the novel in the summer of 1922 .

${ }^{48}$ Kazemi, Tehrān, 5 .

${ }^{49}$ Ibid., 5; own italics.

${ }^{50}$ Shireh is a decoction from opium residues.

${ }^{51}$ Kazemi, Tehrān, 214.

${ }^{52}$ Ibid., 214.

${ }^{53}$ Ibid., 249.

${ }^{54}$ Ibid., 267.

${ }^{55}$ Ibid., 269.

${ }^{56}$ Ibid., 261.

${ }^{57}$ R. Zia-Ebrahimi, The Emergence of Iranian Nationalism: Race and Politics of Dislocation (New York: Columbia University Press, 2016).

${ }^{58}$ Kazemi, Tehrān, 261.

${ }^{59}$ Ibid., 309.

${ }^{60}$ Ibid., 158-9.

${ }^{61}$ Aryanpour, $A z$ Sabā, 262.

${ }^{62}$ M. Berman, All that is Solid Melts into Air: The Experience of Modernity, rev. ed. (New York: Penguin Books 1988 [1982]), 13-14.

${ }^{63}$ Kazemi, Ruzegār, 85.

${ }^{64}$ Ibid., 70 .

${ }^{65}$ Ibid., 120.

${ }^{66}$ Moshfeq remembers witnessing Mirzadeh 'Eshqi performing some of his radical poetry in Tehran during protests against the Anglo-Iranian Treaty of 1919. Kazemi, Ruzegār, 93.

${ }^{67}$ Aloob, The Persian Social, 108-9.

${ }^{68}$ See: D. Shahbazi, 'Epekiyān', Tehrān-nāmeh online resource (Tehran: http://tehrannameh.com); N. Parvin, 'RA'D', Encyclopcedia Iranica, online edition (New York, 1996- [2004]).

${ }^{69}$ Kazemi, Ruzegā $r, 112$. 
${ }^{70}$ P. 516 in M. Eskandari-Qajar, 'Novellas as Morality Tales and Entertainment in the Newspaper of the Late Qajar Period: Yahya Mirza Eskandari’s “Eshgh-e Dorughi” and “Arousi-e Mehrangiz”, Iranian Studies, Vol. 40 (2007), 511-528.

${ }^{71}$ P. 368 in A. Najmabadi, 'The Morning After: Travail of Sexuality and Love in Modern Iran,' International Journal of Middle East Studies, Vol. 36 (2004), 367-385.

${ }^{72}$ Najmabadi, 'The Morning', 369. See also Pedersen, Persian Novel, 127.

${ }^{73}$ Mentioned only as $P \bar{a}-y e$ bokhări in Moshfeq's memoirs. Thanks to my colleague Tine Roesen for identifying the film.

${ }^{74}$ It should be added that according to Pedersen, the second half of the sequel was originally published by the Soviet Consulate of Commerce. Moshfeq does not comment on this in his memoirs.

${ }^{75}$ Kazemi, Ruzegār, 123.

${ }^{76}$ Ibid., 104.

${ }^{77}$ V. Kubickova, 'Persian Literature in the 20th Century' in J. Rypka (Ed.), History of Iranian Literature (Dordrecht: D. Reidel, 1968), p. 391.

${ }^{78}$ See M. Moosa, The Origins of Modern Arabic Fiction, $2^{\text {nd }}$ Ed. (Boulder/London: Lynne Reinner, 1997), 240-245.

${ }^{79}$ Kazemi, Tehrān, 170-1.

${ }^{80}$ For a discussion of Moshfeq's contradictory politics, and the difference between the messages in

Tehrān-e Makhuf and its sequel, see Pedersen, Persian Novel, 129-132.

${ }^{81}$ Kazemi, Ruzegār $, 101,106$.

${ }^{82}$ cf. Razaqpur, 'Naqd-e'; for discussions about authoritarian modernisation, see T. Atabaki and E. J.

Zürcher, Men of Order: Authoritarian Modernization under Atatürk and Reza Shah (London: I. B. Tauris, 2004).

${ }^{83}$ Kazemi, Ruzegār, 118 .

${ }^{84}$ Ibid., 89-90.

${ }^{85}$ Ibid., 37-8.

${ }^{86}$ Ibid., 139.

${ }^{87}$ Ibid., 141.

${ }^{88}$ Ibid., 148.

${ }^{89}$ Ibid., 140.

${ }^{90}$ Pedersen, Persian Novel, 125-6.

${ }^{91}$ For a fascinating account of the emergent bourgeois readership of serialized fiction in 1870s Beirut, see E. M. Holt, 'Narrative and the Reading Public in 1870s Beirut', Journal of Arabic Literature, Vol. 40 (2009), 37-70.

${ }^{92}$ P. Deilami, 'The Bolsheviks and the Jangali revolutionary movement, 1915-1920', Cahiers du monde russe et soviétique, Vol. 31 (1990), 55, Note 5.

${ }^{93}$ R. D. Lehan, The City in Literature: An Intellectual and Cultural History (City: University of California Press, 1998), 55-6. 
${ }^{94}$ L. Kreft, 'Dandy Socialism', Proceedings of the European Society for Aesthetics, Vol. 8 (2016), 17.

${ }^{95} \mathrm{U}$. Eco, 'Rhetoric and Ideology in Sue's Les Mystères de Paris, International Social Science Journal, Vol. 19 (1967), 567.

${ }^{96}$ H. Katouzian, Sadeq Hedayat: The Life and Legend of an Iranian Writer (London: I.B. Tauris, 2002), 11.

${ }^{97}$ See: C. Schayegh, Who Is Knowledgable Is Strong: Science, Class, and the Formation of Modern Iranian Society, 1900-1950 (Oakland: University of California Press, 2009), 17, 19.

${ }^{98}$ A. Matin-Asgari, 'The Berlin Circle: Iranian Nationalism Meets German' in K. S. Aghaie \& A. Marashi (Eds.), Rethinking Iranian Nationalism and Modernity (Austin: University of Texas Press, 2014), 49-66.

${ }^{99}$ See T. Grigor, 'The king's white walls. Modernism and bourgeois architecture' in B. Devos \& C. Werner (Eds.), Culture and Cultural Politics Under Reza Shah (London \& New York: Routledge, 2014). ${ }^{100}$ Schayegh, The Middle East. 